\title{
Are Translators Really SUbSERVIENT? EMPIRICAL EVIDENCE FROM LEXICAL TRANSFER AND Language Prestige in CURAÇAO ${ }^{1}$
}

\author{
COURTNEY G. PARKINS-FERRón \\ Universitat Rovira i Virgili, Tarragona, Spain \\ courtneyparkinsferron@gmail.com
}

\begin{abstract}
This paper examines whether translator subservience is generalisable among translators. Taking professional Curaçaoan Papiamentu translators as a case study built on a much larger work, the research looks at issues of subservience from the perspective of agency in the English-to-Papiamentu lexical transfer process and at the influence of language prestige. The results show instances in which the translators reported more lexical transfers than did the non-translators. The results also reveal an overlooked translator agency in the process rather than translator subservience, in view of the fact that in this process they are on the "frontline", pre-empting whatever decisions the official language planners make.
\end{abstract}

Keywords: agency, language prestige, lexical transfer, Papiamentu translation, sociology of translation

\section{Introduction}

Dam and Korning Zethsen (2008: 73), in a literature survey, succinctly remark that:

[t]he translator is referred to as a "shadowy presence" (Steiner, quoted in Bassnett 2002: 77), invisible, seldom recognized (Venuti 1995: 1, 17) or anonymous (e.g. Koskinen 2000: 60), modest, self-effacing (Godard 1990 in Hatim 2001: 52), isolated (Risku 2004: 190), unappreciated (Vinay and Darbelnet 1958/2000: 92), passive (Risku 2004: 190) and powerless (Snell-Hornby 2006: 172). (cit. Liu 2011: 1)

1 I am grateful to all my colleagues for their valuable comments and help, especially to Prof. Ronald Severing and the staff of the Fundashon pa Planifikashon di Idioma, Willemstad, Curaçao. The responsibility for the many remaining flaws is mine. 
These claims paint a less-than-hopeful picture of the status of translators in general. But, does this mean that translators in their practices everywhere are really subservient?

The present paper examines whether language prestige is influential in determining the extent to which professional translators act as agents when they transfer into their translations lexical items from another language (lexical transfer), and, if so, whether they also do it subserviently. Thus, I approach the issue of subservience from the perspective of agency. The quantitative aspect of the study is based on a questionnaire sample of 100 professional Curaçaoan Papiamentu translators and 105 Papiamentu non-translators. The qualitative aspect develops from an open-ended question in the questionnaire, an interview sample of three official personnel from the language planning institute - the Fundashon pa Planifikashon di Idioma (hereafter FPI) - and an analysis of selected Papiamentu (non)translational texts.

The research questions are: 1) Does language prestige play a role in the translators' transfer of English lexical items into their Papiamentu translations? 2) Do translators report more English-to-Papiamentu lexical transfers than do nontranslators? and 3) What is the translators' and non-translators' justification for their lexical transfer? These questions are important because 1) Papiamentu is historically lexified by Portuguese and Spanish, and 2) in Curaçao it is co-official and co-existent with English and Dutch to which it is not linguistically related. However, it tends to produce some of its new vocabulary from the former, not from the latter (see, for example, Cristinoi 2016; Fuster and Neuser 2017; Trimasse 2018). Further, after enduring centuries of severe repression, mostly under Dutch rule, Papiamentu has succeeded in supplanting the Dutch language, the first official language, to become the official first language of the country. As a result of the struggles of Papiamentu to attain its current status, lexical transfer from other languages is generally discouraged. Nonetheless, it occurs. I suspected, then, that translation is vital in this process hence the agency of the translators amidst issues of language prestige.

In the next section, I shall examine some key literature pertaining to this study by starting with a definition and reviewing some of its characeristics. I shall also consider some alternative definitions. In Section 3 my attention will turn to the methodology of the study, highlighting the research approach adopted, the research instruments, the hypothesis and a model suggesting a relation between translation and lexical transfer. This will be followed by Section 4 presenting the quantitative and qualitative results of the study, while in Section 5 I shall offer a detailed discussion of them. The final section of the paper will contain some conclusions. 


\section{Literature Review}

Regarding the notion of agency understood as a capacity to bring about change, other valuable contributions can also be added to the works mentioned in the Introduction of the present paper. Some of these contributions are Simeoni (1998), Cronin (2003), Milton and Bandia (2009), Chesterman (2010), Pym (2010), Tymoczko ed. (2010), Immonen (2011), Simon (2012), Buzelin (2014), ParkinsFerrón (2016a, 2016b), Young (2017), Castro, Mainer and Page (2017), and Koskinen and Kuusi (2017). In search of novel informative perspectives, Kinnunen and Koskinen (2010: 6) formulated the definition of agency as the "willingness and ability to act". The aspect of "willingness" describes translational transactions in which the translator's behaviour is considered morally and ethically conscious, reflective and intentional (p. 6). The aspect of "ability" is connected to "constraints and issues of power(lessness)" and choice concerning the actions of all the actors, irrespective of their social status, in a translational transaction (p. 6). The aspect of "acting" is a matter of "exerting an influence in the lifeworld" (p. 6) (see also Poupaud 2008; Okyayuz Yener 2010; Haddadian Moghaddam 2011; Joseph-Gabriel 2015).

However, noting that Buzelin (2011: 6) points out various paths of the notion of agency, I shall present two of them here. Milton and Bandia (2009: 1) view an agent of translation as "any entity (a person, an institution, or even a journal) involved in a process of cultural innovation and exchange". The focus of Milton and Bandia's (2009: 1) "agent" seems to be open exchange of ideas between cultures. All of these forms of entity and process can be found in the Papiamentu context. For Simeoni (1995: 452), an agent is "the 'subject', but socialised. To speak of a translating agent, therefore, suggests that the reference is a 'voice', or a pen (more likely a computer today), inextricably linked to networks of other social agents". The focus of Simeoni's (1995) "agent" therefore seems to be a socially networked translation medium (see also Tymoczko 1998; Tymoczko 2010; Boase-Beier 2014; Joseph-Gabriel 2015). Again, this definition fits the Papiamentu context (see also Buzelin 2014). Having considered the merits of the definitions herein proposed and for the purpose of the present study, I decided to adopt Kinnunen and Koskinen's (2010) definition of agency for its brevity, comprehensiveness and overall suitability to my research questions.

As regards translator agency and the attendant issue of subservience, attention must be paid to Simeoni's questions about the power of norms on translators, which he raised in his seminal paper published in Target in 1998. He formulates the hypothesis that "translatorial competence may be characterized by conformity to a greater extent than is the competence of other agents active in the cultural field" (1998: 7). That is, among all the competent parties in a translation transaction, the translator may be more inclined than any of the other parties to follow the accepted way of executing the translation task. Simeoni's justification for his hypothesis is well taken given that he draws on instances that show that literally for ages, translators have not been taken seriously and therefore have 
generally been relegated to a "lower status" among other professions - hence low wages and little or no recognition (see, for example, Venuti 1995; Chan 2008; Liu 2011; Pym 2017). Citing instances from the Spanish Golden Age up through the age of Dryden to the twenty-first century, Simeoni (1998: 7) argues that "[t]ranslators, not unlike the scribes of ancient or premodern civilizations, have always occupied subservient positions among the dominant professions of the cultural sphere" (see also Jänis 1996).

Clarifying that the translator's subservience dates back to Jerome's method of Bible translation, Simeoni (2001) remarks that it is a Christian legacy "acting as a call to order never to move too far away from the source. Such a Christian translation ethics served different interests at different times and was therefore secularized even as it was re-appropriated and reproduced in order to become part of a habitus" (Buzelin 2014: 86). This gave way to two competing models of translation. These were the Ciceronian Republican model and the Hieronymic model. Simeoni (2001) notes that in the former, there was no real distinction between the authorial or translatorial writing. The textual and linguistic norms that Cicero followed were the same in his writing as in his translation. In the latter model, the norms (linguistic and cultural) that Jerome followed at different times were different in his translation from those applied in his writing. Simeoni (2001) holds that the eventual internalisation of Jerome's translation attitude was the result of his repetition and conveyance of it under the different purposes it served. Buzelin (2014: 67) acknowledges Simeoni's (2001) location of the origins of [the] translator's subservience much deeper and further back in time, in a Christian ethics of translation expressing itself in a posture of extreme respect towards a venerated source [and that] this thesis challenges Venuti's [1995, 1998] explanation of the low socio-economic status of the profession, and historical accounts that regard the Roman tradition represented by Cicero as the cradle of Western translation. Conversely, it is very much in tune with Douglas Robinson's (1996), and bears the same implications. (Buzelin 2014: 67)

Further, she clarifies in this debate that Simeoni's (2001) position is not a call to interpret contemporary theories of translation as synonymous with "simple somatised theology" as seen in Robinson (1996, xii, quoted in Buzelin 2014: 67). It is a call instead to interpret both Berman's (1995) and Venuti's (1995) "neoliteralist ethics of translation as modern expressions of the ancient hieronymic posture" (Buzelin 2014: 67). If Simeoni's (2001) thesis is correct, neither Berman's (1995) nor Venuti's (1995) ethics of translation could further be seen as potentially emancipating or revolutionising (Buzelin 2014).

The foregoing research efforts are insightful and influential. However, none of them has investigated subservience in translators directly by considering the role that language prestige plays in their agency through lexical transfer. The present study, part of a much larger research, is the first of its kind to examine this issue, using real data, and hopes to shed some light on a few of the much-debated issues around translator subservience. 


\section{Methodology}

The present study adopts a mixed-methods approach in which the data-collection carried out in Curaçao consisted of a combination of questionnaires, (non)translational Papiamentu public-health medical texts, and interviews. Hence the study is triangulated to produce a sufficiently rich and perceptive investigation.

\subsection{The questionnaire}

Self-reported data from (non)translators were gathered through a questionnaire consisting of 51 questions. Besides questions asking for biographical data, source and target languages, attitude toward lexical transfer, text types and types of lexical transfer, the respondents were asked questions on issues of language prestige. Also, to elicit their reasons for their lexical transfer practice, they were asked: "What factors motivate you to borrow English expressions from the English texts you translate into Papiamentu?" / "What factors motivate you to borrow English expressions into your Papiamentu writing, publishing or editing?"

\subsection{The (non)translational Papiamentu texts}

I limited my investigation to public-health medical texts because they are written simply enough for the general public to be able to read and understand them, and any Curaçaoan could relate to them. Therefore, the texts chosen for this study are from doctors' offices, hospitals, medical laboratories, the Ministry of Public Health, the Departamento Salu Hubenil (Department of Youth Health Care) and other health organisations.

\subsection{The interviews}

The format best suited to the present study was decidedly the standardised openended interview structured on the same independent variable (language prestige) as for the questionnaire. This was to facilitate the eventual merging and interpretation of results. All the questions were asked of official language planners in exactly the same way each time of each participant in order to elicit full detailed responses and the same kind of information, hence the avoidance of potentially inconsistent questions that could be due to spontaneous reformulations of them. 


\subsection{Research hypothesis and variables}

The hypothesis is: Translators report making more lexical transfers than do nontranslators when the lexifier language is more prestigious. The variables are therefore lexical transfer activity and language prestige.

The lexical transfer variable, for the purposes of the present study, refers to the use of any English lexical item in a Papiamentu text for expressing an idea or part thereof, irrespective of whether the item is a quotation of someone's utterance or whether a corresponding Papiamentu expression exists. The variable is dependent, discrete and measured by the self-report assessment from the questionnaire respondents with respect to the frequency of lexical transfers into their (non)translations. Therefore, on a 5-point Likert scale, where $5=$ always, $4=$ frequently, $3=$ occasionally, $2=$ rarely, $1=$ never , the reported frequency can be estimated.

The language prestige variable, for the purposes of the present study, refers to the way in which the respondents perceived the worth of their language (Papiamentu) relative to another language (in this case, Dutch, English or Spanish) that might be given some prestige over it with respect to the political and educational life of their society. This variable is independent, and although naturally continuous, it is analysed here as discrete and operationalised through a self-report assessment from the questionnaire respondents.

\subsection{The Papiamentu translators and non-translators}

For the purposes of the present study, the definitions provided by Parkins-Ferrón (2013) are used. A professional Papiamentu translator is anyone who for payment expresses in written form the ideas of an English source text in Papiamentu, thus creating a Papiamentu translation. A Papiamentu non-translator is anyone who for payment produces (that is, writes, publishes or edits) a text originally in Papiamentu, hence a Papiamentu non-translation. Both the translator and nontranslator account for such constraints as culture, context, grammar rules, writing conventions and idiom of the target language and also of the source language of lexical transfer.

Among the set of (non)translators in Curaçao, there are exclusive translators (T) who only translate. The term "exclusive" denotes that they do not engage in non-translational writing. Additionally, there are translators who also write nontranslations (writing translators, or wT), writers who also translate (translating writers, tW), those who produce translations just about as much as they produce non-translations (writers/translators, WT), and the non-translators (W) who only produce non-translations. Thus, the distribution of (non)translators can be considered as a spectrum where the exclusive translators are found at one end and the non-translators at the other. All others (wT, WT, tW) are to be found between these two extremes and are referred to as translators-and-writers. 


\subsection{A model of the relation between translation and lexical transfer}

In this model there are two levels of communication - formal and informal. While an authoritative body may not be able to control lexical transfer at the informal level, it can do so at the formal level where a relation between the processes of lexical transfer and language standardisation exists. As standardisation essentially involves official intervention, I suspect that between these two processes, there is not merely a relation but a deliberate overlapping of them involving translators, non-translators, and language planners. In these processes, those who write and/or translate produce more and more texts in their creole, and by that token, introduce lexical items that may become officially documented in it from other languages albeit generally without any mention of translation being involved.

However, lexical transfer becomes a concern in the decision-making process of what to standardise and what not to standardise. It is part of a "push-pull" process in which (non)translators, on the one hand, engage in transferring lexical items from one language to their creole and use them unofficially. Some (non)translators may eventually come into contact with the language-planning authorities to verify the use of certain lexical items. This act may constitute the "push" to have them officially documented.

On the other hand, the language-planning authorities' intervention to decide which of the active transferred lexical items will be documented in the standard creole lexicon constitutes the "pull". This "push-pull" process points to a relation between translation and the lexical transfer processes, which in turn would then imply an overlooked agentive involvement of translation (hence of translators) in the lexical transfer process itself. Thus, the creole translators would be on the "frontline" where they use and therefore transfer lexical items into their creole long before the language planners set their guidelines in place. This would mean that the contribution of translators in the standardisation process cannot be regarded as subservient as their involvement may well pre-empt whatever the language planners ultimately decide, thereby underscoring the importance of the translators in the lexical transfer process (see Appendix: Figure 1).

Briefly, this model implies a relation between translation and lexical transfer because the latter occurs through translation. With this model, I now turn to the results of the study.

\section{Results}

\subsection{The questionnaire}

\subsubsection{Inferential statistical tests}

The results of the statistical tests were computed by SPSS to compare the lexicaltransfer activity of the translators and non-translators by language prestige. All 
205 respondents answered appropriately to the questions asked. The questions and the formulated hypothesis are as follows:

Q. 1: "Do you borrow English expressions into your Papiamentu texts when you think English is seen as more prestigious than Papiamentu with respect to the nature of the text?"

Q. 2: $\quad$...when you find no corresponding expressions in Papiamentu?"

Q. 3: ...when you think Papiamentu speakers use the English expression at least as frequently as they use the Papiamentu one?"

Q. 4: ...when you think the English expression sounds better than the Papiamentu one?"

Q. 5: ...when you think the English expression does not make the meaning of your Papiamentu text in any way unclear?"

Q. 6: ...when you think the English expression makes the meaning of your Papiamentu text clearer?"

Q. 7: ...when you think the English expression helps to build up the Papiamentu vocabulary and keep the language standardised?"

Q. 8: ...when you think Papiamentu speakers will not object to the use of the English expression?"

Recalling that the hypothesis is: Translators report making more lexical transfers than do non-translators when the lexifier language is prestigious, I conducted an Analysis of Variance (ANOVA) test on the sample as a whole to determine the impact of the prestige of the lexifier language on the lexical-transfer activity of the respondents. The results were statistically significant $(\mathrm{F}=824.280$, $\mathrm{p}=<0.001$ ). The Pearson's correlation coefficient is 0.686 , a strong positive association indicating for this sample that the respondents who considered English as more prestigious were more inclined than those who did not, to use English in their Papiamentu (non)translations. The ANOVA test therefore suggests that language prestige plays a meaningful role in lexical transfer.

However, further hypothesis testing was required to identify whether a significant difference existed between the ordinal responses of the translators, translators-and-writers and non-translators to the items in the questionnaire. The Kruskal Wallis two-tailed test meets this capability and was therefore used for further testing the hypothesis at $\alpha=.05$. The test also assumes that the frequency distributions of the three independent groups of responses (measured on an ordinal scale from $1=$ "Never" to $5=$ "Always") could be meaningfully ranked in an order of magnitude. The null hypothesis was that the grouped median scores for each group of respondents were equal. The decision rule was to reject the null hypothesis if $\mathrm{p}<0.05$ for the Chi-Squared $\left(\chi^{2}\right)$ statistic, meaning that at least one of the grouped median scores was significantly greater or less than the others. The results are presented below. 
On the one hand, the results of further testing show that the non-translators reported making more lexical transfer than did the translators in five of eight cases. These are when they, the non-translators, thought that English was seen as more prestigious than Papiamentu with respect to the nature of the text $\left(\chi^{2}=12.50\right.$, $\mathrm{p}=.002$, Cramér's Phi $\left(\varphi_{\mathrm{c}}\right)=.17$ for a very weak positive correlation between the lexical transfer and the language prestige variables), when they thought that the English expression sounded better than the Papiamentu one $\left(\chi^{2}=57.737, \mathrm{p}<0.001\right.$, $\varphi_{\mathrm{c}}=.38$ for a moderate positive correlation), when they thought the English expression did not make the meaning of their Papiamentu text in any way unclear $\left(\chi^{2}=28.192, p<0.001, \varphi_{c}=.26\right.$ for a weak positive correlation), when they thought the English expression made the meaning of their Papiamentu text clearer $\left(\chi^{2}=30.915, p<0.001, \varphi_{c}=.27\right.$ for a weak positive correlation $)$ and also when they thought the English expression helped to build up the Papiamentu vocabulary and keep the language standardised $\left(\chi^{2}=13.096, p=.001, \varphi_{c}=.18\right.$ for a very weak positive correlation). In each of these five cases, the non-translators had the highest grouped median scores.

On the other hand, the exclusive translators were found to report more lexical transfer than were the other respondents in two out of eight cases, that is, when they found no corresponding expressions in Papiamentu $\left(\chi^{2}=17.732, p<0.001, \varphi_{c}=\right.$ .21 for a weak positive correlation) and when they thought that Papiamentu speakers used the English expression at least as frequently as they used the Papiamentu one $\left(\chi^{2}=14.057\right.$ and $p<0.001, \varphi_{c}=.19$ for a very weak positive correlation). In each of these two cases, the exclusive translators had the highest grouped median scores. There was only one case for which I could not confirm the hypothesis as the responses did not vary significantly between the respondents with respect to whether they used English expressions in their Papiamentu texts because they thought Papiamentu speakers would not object to the use of the English expressions $\left(\chi^{2}=1.947, p=.378\right)$ (see Appendix: Table 1).

\subsubsection{Open-ended motivation question}

With respect to the open-ended motivation question, "variety of expressions / flexibility for clarity" was the reason most reported for lexical transfers. Fifty-five percent of the exclusive translators claimed this as a factor. Among the translatorsand-writers, $39 \%$ claimed this as a factor, followed by $23 \%$ of the non-translators. Although only $23 \%$ of the non-translators reported this as a factor, $47 \%$ of the translators did so. Conversely, the reason that was least reported among all the translators was "consumer appeal / marketing" with only $3 \%$. However, this percentage is solely for the exclusive translators as none of the translators-andwriters reported this as a factor for their lexical transfers (see Appendix: Table 2 and also Parkins-Ferrón 2015). 


\subsection{The (non)translational texts}

Four common types of lexical transfer were identified in the Papiamentu texts and are discussed here according to the methods of translation outlined in the seminal work of Vinay and Darbelnet (1958/1995: 85).

Unmodified borrowing - the use of lexical items without any morphological modification in Papiamentu texts: for example, "coronary care", "deposit", "public health nurse".

Modified borrowing - the use or transcription of a lexical item in the form of a morphological translation: for example, keyboardnan for "keyboards" or newsletternan for "newsletters", workshopnan for "workshops", where the suffix -nan is a plural marker in Papiamentu.

Morphophonetic translation - the borrowing of an expression form of another but translating literally each of its elements. The result is a structural parallelism, or "structural calque", "which introduces a new construction into the language" as seen in the following examples: dèshbort for "dashboard", lèptòp for "laptop", laiter for "lighter" and winshil for "windshield". Thus, the lexical items have undergone a translation that is morphological, phonetic and phonological simultaneously.

Syntactic imitation - a borrowing in which the resulting calque is lexical and "respects the syntactic structure of the TL [target language], whilst introducing a new mode of expression" as in the examples of mi nta wòri for "I'm not worrying", and lebumai, lègumai, and leumai for "never mind".

Many lexical items, including these given here as examples, have in fact been in the language for many decades (see also Maduro 1966; Wood 1971; FPI 2009; Parkins-Ferrón 2015).

\subsection{The interviews}

The three interviewees, to whom I have given the fictitious names Kyu, Val and Nat, had been working for the FPI up to the time of the interviews.

Kyu has doctoral-level education and had been a published language planner and university lecturer for more than 20 years.

Val has a Master's-level education, is also a published language planner, a Papiamentu, Dutch, English and Spanish translator, had taught in the high school system for more than 25 years and at the University of Curaçao for more than 15 years.

Nat had focused more on orthography and lexicography, with an involvement of more than 15 years. Prior to her language planning engagement, she had worked as a Spanish teacher and translator of Papiamentu, Dutch, English and Spanish.

When I asked about the extent to which they see Papiamentu as prestigious on the island, in comparison with the other languages, Nat responded that the use of 
Papiamentu on the island has always depended on who is being addressed. As long as the audience is Papiamentu-speaking, it is Papiamentu that is the language of communication.

" $[\mathrm{N}]$ owadays, the young people are using a lot of English when they speak. If you had asked me this one year ago, I would have said English is not so commonly used, and ... I would have said Spanish": [...] then comes a period of Papiamentu stabilising [...]. But lately, in the last years, I have noticed that the young people use a lot of English words. I think it is influence from the Internet $[\ldots]$ and everything will be related to computers $[\ldots]$ (Nat)

Nat spoke as though the impact of Spanish were inescapable. There are those who like to use Spanish in their Papiamentu but not because they feel that Spanish is more prestigious. Rather it is because so much of the language is relatively easy to adapt to Papiamentu. She offers the example of the word ainda ("still", "yet"), a word that comes from Portuguese and which they have always heard from their mothers and grandmothers. But now many people say aún, which is Spanish for "still" and "yet":

We did not grow up with aún. But now it's the big thing because we have a lot of people from Santo Domingo, from Colombia... And maybe they are using it in the [Papiamentu] language, and then because the Papiamentu speakers understand this, they just do it too. (Nat)

Also, Nat pointed out another language situation involving the clergy:

We have a lot of priests from Spanish-speaking countries... When they preach, they use Papiamentu. But then when they cannot come up with real Papiamentu words, they use their language, and people take it. Like entronar [enthrone]. Last week somebody called and asked if entronar is a correct Papiamentu word. But it means they hear it from the priest! (Nat)

Further on in the interview with her, I discovered that amid the efforts to standardise the language and produce texts in it, there seems to be a different effect of translation upon Papiamentu with respect to English religious texts translated into Papiamentu. Where translation of religious songs is concerned, she did not notice any lexical transfer as such but a phenomenon that she referred to as the "English way of translating". I gathered that what she meant by that was that the Papiamentu target text had an English "feel" to it, a result that is easily achievable by direct translation, of which literal translation is one form (see Vinay and Darbelnet 1958/2000):

What I can say is... religious groups [...] take English songs, and they translate them into Papiamentu. They don't use the English words; that's okay. But they use the English way of saying things. You see, when you sing a song in Papiamentu, it's not a real Papiamentu ... it's not the real way we translate; it's translated literally producing an unreal Papiamentu, not the way we say things. Sometimes even if the words are Papiamentu words, it's like you are reading 
English. When they are praying they say for instance: Yama riba Spiritu. It's a translation for "Call upon the Holy Spirit". Indeed "call" is yama and "upon" is riba, but yama riba means nothing! A correct translation would be Invoká Spiritu Santu. You don't even need two words [for "call upon"]! (Nat)

Nat's observation is valid and worthy of investigation. In fact, this issue could be examined from the angle of activist translation, as discussed by Tymoczko ed. (2010), who notes that translators are viewed as key agents for social change and translations are recorded as vital cultural expressions and not as imitative, peripheral or side-lined productions. Also, translation is seen as a political, ethical and ideological exercise, not merely as a perfunctory linguistic transposition of text (see, for example, Joseph-Gabriel 2015). Therefore, questioning the motives of the translators is always in order.

None of the language planners mentioned they experienced any pressure to accept English words into Papiamentu. However, Val and Kyu said that pressure seems to come more from the decisions that they have to make with respect to lexical items that are generated from Papiamentu's own historical resources and which may be in dispute, especially because of existing variants of them. Both remarked that most of the information concerning law and medicine is in Dutch not because this language is viewed as more prestigious than Papiamentu but more because the body of information in them is not yet completely available in Papiamentu, given that this language was just made official in 2007. However, these disciplines among others now favour English more than Dutch mainly owing to the international nature of the former and anticolonial sentiments toward the latter. All three interviewees agreed that although the general consensus of Papiamentu speakers is to promote Papiamentu with pride, the FPI is a planning agency responsible for promoting all four languages on the island for the right purposes and in the appropriate contexts. All three official languages (Papiamentu, Dutch and English) are equally prestigious in theory. However, people have their opinions, choices and preferences for one language over another, and they are entitled to that.

\section{Discussion}

To determine appropriately whether the translators in this study acted subserviently amidst issues of language prestige and to appreciate their agency, it is important to consider their justification (in their own words) for their lexical transfer practice. It is also crucial to consider: 1) Simeoni's (1995: 452) view of an agent as 'the 'subject', but socialised [...] a 'voice,' or a pen (more likely a computer today), inextricably linked to networks of other social agents"; 2) Toury's (1995: 267-274) "law of growing standardization" (also referred to as the law of conversion), which suggests that "in translation, source-text textemes tend 
to be converted into target-language (or target-culture) repertoremes"; 3 ) Toury's (1995: 267-279) "law of interference", which suggests that the source text interferes in the target text by default; 4) Simeoni's (1998: 7) painstakingly formulated hypothesis that the "translatorial competence [of the translator] may be characterised by conformity to a greater extent than is the competence of other agents active in the cultural field" (1998: 7); and 5) Kinnunen and Koskinen's (2010) definition of agency as the "willingness and ability to act". I shall examine these ideas in the context of my findings.

Respondent 12, a male exclusive translator trained in landscape architecture, said that "prestige is not always so clear from field to field. It all depends on the purpose of the text, who the audience is and who is talking." This comment seems to suggest that the choice of language in a given situation or text should not be taken to be necessarily synonymous with prestige, as there are valid reasons for the choice and may have nothing to do with prestige.

Respondent 150, a female non-translator who works in text production, said "[i]t is not so much about being 'prestigious' [as] it is about the [English] words being internationally established and accepted to contribute to a good understanding." She acknowledged that transferred lexical items could enhance textual meaning and that attention should be paid to this potential rather than to which language is more prestigious.

Respondent 62, a female writer/translator formally trained in translation, said, "[j]ust because I cannot find a corresponding expression in Papiamentu, it does not mean that the expression does not exist." She further said "[i]f I cannot find an appropriate expression, I consult my colleagues or contact the university language department or even call the language planning institute..." The language planners themselves have mentioned that they get calls of this kind from time to time and have indicated that it is sometimes out of these calls that suggestions emerge for the on-going compilation of the Buki di oro, for example. This comment points to the fact that the translators' method of finding solutions by networking with colleagues and even with the formal authorities aligns with Simeoni's (1995: 452) view of an agent as "the 'subject', but socialized [...] inextricably linked to networks of other social agents"

Respondent 93, a female writing translator formally trained in translation, said "I think the English expression makes the text clearer [...] when Papiamentu speakers are more accustomed to seeing [...] the English expression than the Papiamentu expression." She mentioned the automobile industry as an example of high-frequency use of English terms, saying, "It is more normal to find the parts of a vehicle in English, although the words may be written in the Papiamentu way sometimes." The language planners also explained that the words they keep in Papiamentu sometimes have to do with deciding which ones they can write according to their Papiamentu orthography.

The foregoing comments indicate that consideration of the target audience and/or the client is crucial for the (non)translators' decision to use English expressions in their Papiamentu (non)translations. Toury (1995: 267-274), in his 
discussion of his proposed "law of growing standardization", says "in translation, source-text textemes tend to be converted into target-language (or target-culture) repertoremes". However, some of the comments by the translators and nontranslators above suggest that this does not necessarily hold. In the general case of the translators, the finding was that when the English expression was used at least as often as the Papiamentu one, the translators opted for the English one. Clearly, they did not act in this manner just because they thought that English was more prestigious than Papiamentu; the non-translators did. This means that for some translators, their reason for engaging in lexical transfer had to be other than any suggestable by Toury's law of growing standardisation.

Also, Toury's (1995: 274) "law of interference" suggests that the source text interferes in the target text by default. This happens when the source-language culture is more powerful, or prestigious than that of the target language. Again, my research findings with respect to language prestige have shown that this is not necessarily the case. Some of the translators clearly state that they steer clear of lexical transfer when they translate from English into Papiamentu. Some have even indicated that their decision to use English in their translations has to do with the request of their clients to whom they render their services rather than with one language being more prestigious than the other. This point about respecting the client's wishes in the translational transaction leads to Simeoni's $(1995,1998)$ argument about the translator being subservient. Accordingly, Buzelin (2014: 86) sounds a note of caution that, as provocative as Simeoni's hypothesis and findings may be, they do not suggest that every translator follows translation norms to the same extent or that they do not have the ability to be "creative and cunning in designing translation strategies". They do not suggest that translators in general are not proud of their profession and are reluctant to promote it nor do they counter the possibility of dissimilarities in translation practices between cultures, nations, historical eras or professional fields. Rather, they affirm that "translators, at least in the West, have internalised the idea that their practice defines itself by its secondariness and in opposition to authorial writing" (Buzelin 2014: 86; see also Pym 2011, 2017). Understanding this, I can now address Simeoni's (1998) hypothesis and his questions pertaining to the power of norms over translators.

Once the Papiamentu translators have come to terms with certain realities in respect of the multilingual character of their country, Curaçao, with the blatant need to build specialised terminology in the language, with the fact that they are not in a position to wait for specialised terminology to become available in Papiamentu, with the place of English in international marketing, and with the fact that their translations serve purposes that go beyond the text "exerting an influence in the lifeworld" (Kinnunen and Koskinen 2010: 6), it becomes evident that they are not averse to breaking "existing norms"; they therefore certainly do not at all present themselves as being "plain submissive" (see Simeoni 1998: 7).

Briefly, the fact that some of the language planners are also translators attests to the relation between English-to-Papiamentu translation and the lexical-transfer 
process. These are instances not of subservience but of agency acted out willingly by the Papiamentu translators and non-translators because they are able to do so, and also because they understand the impact of their lexical-transfer practice.

\section{Conclusion}

This study fundamentally sought to address the issue of whether translators are generally subservient in their translation practice. The results show that the translators in this study acted as agents of lexical transfer and that language prestige plays a role in this process. The study does not at all suggest that a translator is subservient just because they are working. What it suggests is that in the lexical transfer process, the translators are on the "frontline" where they possibly function as vibrant and innovative users of lexical items they transfer into Papiamentu long before the FPI establish their guidelines. This finding aligns with the model I proposed in my methodology. However, this study does not claim that language prestige is the only factor that can inform us on subservience as other factors not tested here may also be responsible (see also Parkins-Ferrón 2015).

Further, the respondents who transferred lexical items through their (non)translations were willing and able to do so. Over three quarters $(77 \%)$ of all the translators and $96 \%$ of the non-translators in this study had training in a profession besides translation or writing. Nearly three quarters of the translators $(71 \%)$ and over half of the non-translators $(56 \%)$ practise another profession alongside their translation or writing. It is therefore unlikely that most of the translators in this study practise their translation in the frame of a subservience that is peculiar to translation.

Finally, theories occasionally make for generalisations that fall short of considering important aspects of the reality of translators who may be acting as agents of change in unsuspected places. Despite the FPI's strict monitoring of Papiamentu, they do not "tie the hands" of the translators. Rather, they collaborate with them and the general population, thus giving way to lexical transfer by consensus rather than by fiat. The overall results of this research thus point to a persistent need for more behavioral research on translators in different societies and cultures. 


\section{References}

Berman, Antoine. 1995. Pour une critique des traductions: John Donne. Paris: Gallimard.

Boase-Beier, Jean. 2014. Stylistic approaches to translation: Translation theories explored. New York and Oxon: Routledge. https://doi.org/10.4324/9781315759456

Buzelin, Hélène. 2011. Agents of Translation. In Yves Gambier and Luc van Doorslaer (eds.), Handbook of Translation Studies. vol. 2, 6-12. Amsterdam and Philadelphia: John Benjamins.

Buzelin, Hélène. 2014. How Devoted Can Translators Be?: Revisiting the subservience hypothesis. Target. 26(1). 63-97. https://doi.org/10.1075/target.26.1.03buz

Castro, Olga, Mainer, Sergi, and Svetlana Page. (eds.), 2017. Self-Translation and Power: Negotiating Identities in European Multilingual Contexts. London: Palgrave Macmillan.

Chan, Andy Lung Jan. 2008. Information Economics, the Translation Profession and Translator Certification. Doctoral dissertation. Tarragona: Universitat Rovira i Virgili.

Chesterman, Andrew. 2010. Why Study Translation Universals? In Rita Hartama-Heinonen and Pirjo Kukkonen (eds.), Kiasm (= Acta Translatologica Helsingiensia (ATH). [Online] vol. 1, 38-48. Helsinki: Helsingfors Universitet. Available from: https://helda.helsinki.fi/bitstream/handle/10138/24319/ATH\%20vol\%201\%20art\%204\%20Ch esterman.pdf?sequence $=1 \&$ origin=publication_detail. [Accessed: 15th January 2013].

Cristinoi, Antonia. 2016. Translating between Typologically Different Languages or the Utopia of Equivalence: 1 vs 1.round, 1.long or 1.nasty being. In Larisa Ilynska and Marina Platonova (eds.), Meaning in Translation: Illusion of Precision. vol. 1, 99-109. Newcastle upon Tyne: Cambridge Scholars Publishing.

Cronin, Michael. 2003. Translation and Globalization. Routledge.

Dam, Helle, and Karen Korning Zethsen. 2008. Translator Status: A Study of Danish Company Translators. The Translator. 14(1). 71-96. https://doi.org/10.1080/13556509.2008.10799250

Fundashon pa Planifikashon di Idioma. 2009. Ortografia i Lista di palabra Papiamentu. Curaçao: Fundashon pa Planifikashon di Idioma (FPI).

Fuster, C. and Neuser, Hannah. 2017. Exploring Intentionality in Lexical Transfer. Manuscript in Preparation.

Haddadian Moghaddam, Esmaeil. 2012. Agency in the Translation and Production of Novels from English in Modern Iran. Doctoral dissertation. Tarragona: Universitat Rovira i Virgili.

Immonen, Sini. 2011. Unravelling the Processing Units of Translation. Across Languages and Cultures. 12(2). 235-257. https://doi.org/10.1556/Acr.12.2011.2.6

Jänis, Marja. 1996. What Translators of Plays Think about Their Work. Target. 8(2). 341-364. https://doi.org/10.1075/target.8.2.08jan

Joseph-Gabriel, Annette. 2015. Creolizing Freedom: French-Creole translations of liberty and equality in the Haitian Revolution. Slavery and Abolition: A Journal of Slave and Post-Slave Studie. 36(1). 111-123. https://doi.org/10.1080/0144039X.2014.888869

Kinnunen, Tuija, and Kaisa Koskinen (eds.) 2010. Translators' Agency. Tampere: Tampere University Press.

Koskinen, Kaisa and Päivi Kuusi. 2017. Translator Training for Language Activists: Agency and Empowerment of Minority Language Translators. Trans-kom. [Online] Translation and Fachkommunication Database 10 (2). 188-213. Available from: http://www.trans-kom.eu [Accessed: 20th April 2018].

Liu Fung-Ming Christy. 2011. A Quantitative and Qualitative Inquiry into Translators' Visibility and Job-related Happiness: the case of Greater China. Doctoral dissertation. Tarragona: Universitat Rovira i Virgili.

Maduro, Antoine. 1966. Procedencia di palabranan papiamentu i otro anotacionnan. Letter $N$ te ZJ. 2. 1-20.

Milton, John, and Paul Bandia (eds.) 2009. Agents of Translation. Amsterdam and Philadelphia: John Benjamins. https://doi.org/10.1075/btl.81 
Okyayuz Yener, Şirin. 2010. Translating Turkish Foreign Policy from English into Turkish. Meta. 55(2). 338-354. https://doi.org/10.7202/044244ar

Parkins-Ferrón, Courtney. 2013. Taking the Bull by the Horns: Professional Curaçaoan Papiamentu translators and writers facing the challenges of globalization head-on. In Nicholas Faraclas, Ronald Severing, Christa Weijer, Elisabeth Echteld and Wim Rutgers (eds.), Researching the Rhizome: Studies of Transcultural Language, Literature, Learning, and Life on the ABC Islands and Beyond. vol. 1, 347-363. Curaçao / Puerto Rico: Fundashon pa Planifikashon di Idioma / Universidat di Kòrsou / Universidad de Puerto Rico, Río Piedras.

Parkins-Ferrón, Courtney. 2015. Target-audience Location and Agency in Translation: The case of Curaçaoan Papiamentu. In Nicholas Faraclas, Ronald Severing, Christa Weijer, Elisabeth Echteld and Wim Rutgers (eds.), Envisioning the greater Dutch Caribbean: Transgressing geographical and disciplinary boundaries. vol 1, 159-177. Curaçao / Puerto Rico: Fundashon pa Planifikashon di Idioma / Universidat di Kòrsou / Universidad de Puerto Rico, Río Piedras.

Parkins-Ferrón, Courtney. 2016a. Self-reported Practices of Professional Curaçaoan Papiamentu Translators and Writers: A Window on Their Influence on Papiamentu Standardization. In Larisa Ilynska and Marina Platonova (eds.), Meaning in Translation: Illusion of Precision. vol. 1, 299-318. Newcastle upon Tyne: Cambridge Scholars Publishing.

Parkins-Ferrón, Courtney. 2016b. A Sea of Translation Challenges: An Essay in Caribbean Creole Translation Studies. In Nicholas Faraclas, Ronald Severing, Christa Weijer, Elisabeth Echteld, Wim Rutgers, and Robert Dupey (eds.), Embracing Multiple Identities: Opting out of neocolonial monolingualism, monoculturalism and mono-identification in the Dutch Caribbean. vol. 1, 203-218. Curaçao / Puerto Rico: Fundashon pa Planifikashon di Idioma / Universidat di Kòrsou / Universidad de Puerto Rico, Río Piedras.

Poupaud, Sandra. 2008. Agency in Translation, Hispanic literature in France, 1984-2002. In Anthony Pym and Alexander Perekrestenko (eds.), Translation Research Projects. vol. 1, 3748. Tarragona: Intercultural Studies Group.

Pym, Anthony. 2010. Exploring Translation Theories. London and New York: Rouledge. https://doi.org/10.4324/9780203869291

Pym, Anthony. 2011. The Translator as Non-author, and I am Sorry about That. In Claudia Buffagni, Beatrice Garzelli and Serenella Zanotti (eds.), The Translator as Author: Perspectives on Literary Translation. 31-43. Berlin: LIT.

Pym, Anthony. 2017. Translation and Economics: Inclusive communication or language diversity? Perspectives, 25(3). 362-377. https://doi.org/10.1080/0907676X.2017.1287208

Robinson, Douglas. 1996. Translation and Taboo. DeKalb: Northern Illinois University Press.

Simeoni, Daniel. 1995. Translating and Studying Translation: The view from the agent. Meta. 40(3). 445-60. https://doi.org/10.7202/004146ar

Simeoni, Daniel. 1998. The Pivotal Status of the Translator's Habitus. Target. 10(1). 1-39. https://doi.org/10.1075/target.10.1.02sim

Simeoni, Daniel. 2001. Traduire les sciences sociales. L'émergence d'un habitus sous surveillance: Du texte support au texte-source. Doctoral dissertation. Paris: École des hautes études en sciences sociales.

Toury, Gideon. 1995. Descriptive Translation Studies and beyond. Amsterdam and Philadelphia: John Benjamins. https://doi.org/10.1075/btl.4

Trimasse, Naima. 2018. The Source of Lexical Transfer in L3 Production in a Diglossic Context. International Journal of Multilingualism. 1-13. https://doi.org/10.1080/14790718.2018.1428328

Tymoczko, Maria. 1998. Computerized Corpora and the Future of Translation Studies. Meta. 43(4). 652-659. https://doi.org/10.7202/004515ar

Tymoczko, Maria. (ed.) 2010. Translation, Resistance, Activism: An overview. Amherst: University of Massachusetts Press. 
Tymoczko, Maria. 2010. The Space and Time of Activist Translation. In Maria Tymoczko (ed.), Translation, Resistance, Activism: An overview. 227-254. Amherst: University of Massachusetts Press.

Venuti, Lawrence. 1995. The Translator's Invisibility: A History of Translation. London and New York: Routledge.

Venuti, Lawrence. 1998. The Scandals of Translation. London and New York: Routledge. https://doi.org/10.4324/9780203269701

Vinay, Jean-Paul, and Darbelnet, Jean. 1958/2000. A Methodology for Translation. (J. C. Sager and M.-J. Hamel, trans.). In Lawrence Venuti and Mona Baker (eds.), The Translation Studies Reader. 84-93. London and New York: Routledge.

Wood, Richard. 1971. The English Loanwords in Papiamentu, Nieuwe West-Indische Gids. 48. 17389. https://doi.org/10.1163/22134360-90002217

Young, Robert J. 2017. The Dislocations of Cultural Translation, PMLA. 132(1). 186-197. https://doi.org/10.1632/pmla.2017.132.1.186 


\section{Appendix}

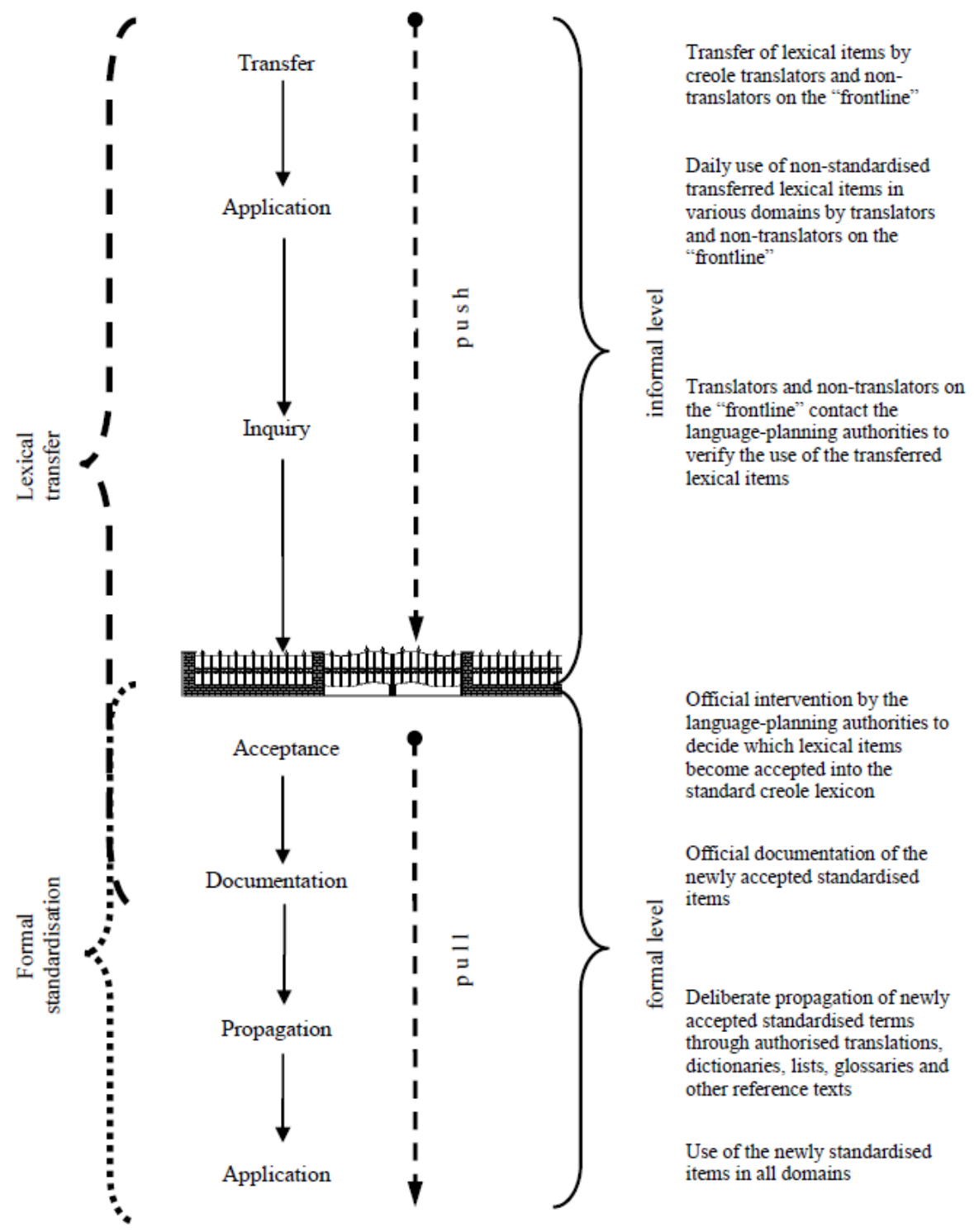

Figure 1: A model of the relation between translation and lexical transfer 
Table 1. Comparison of ordinal responses to questions 1 through 8

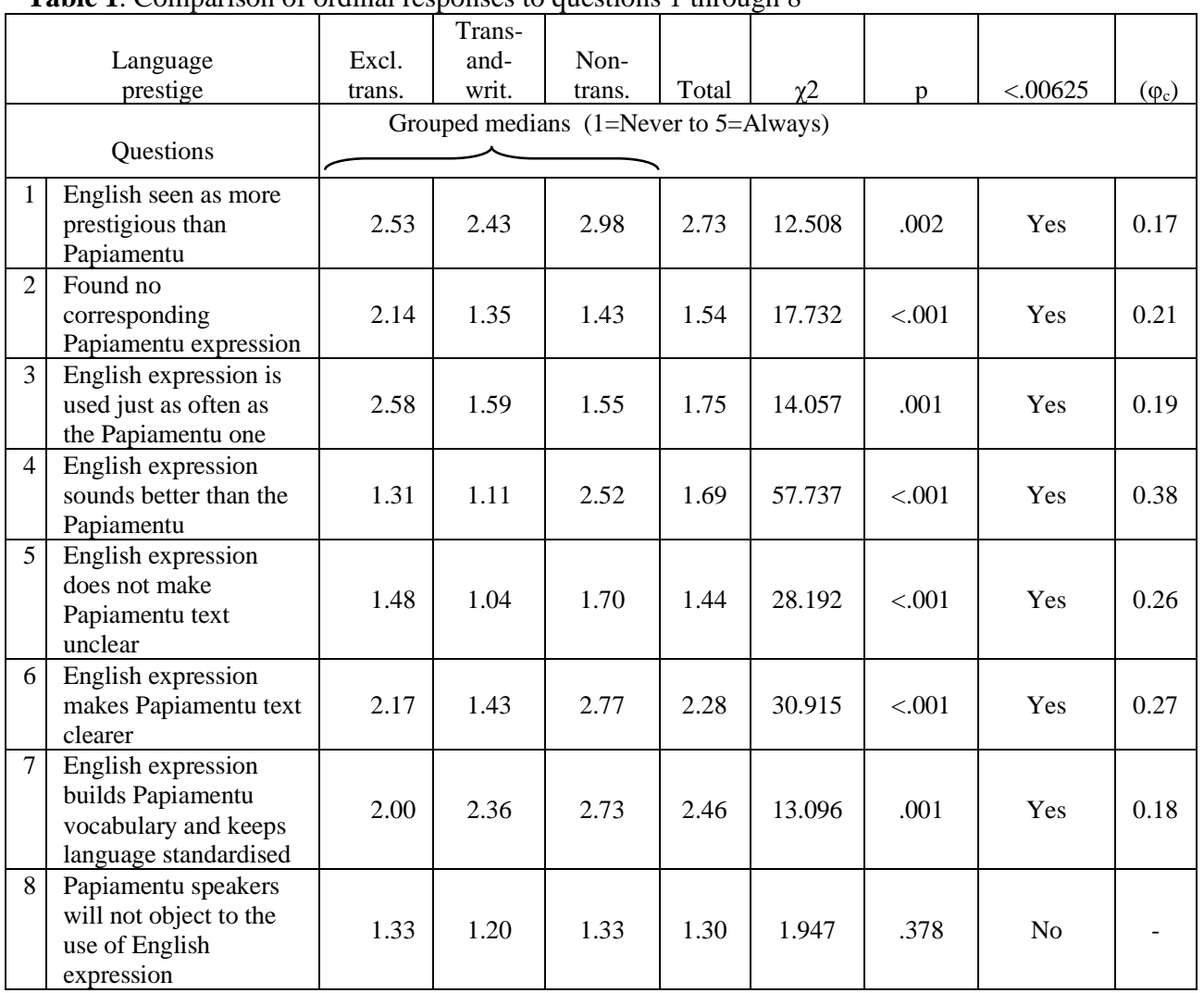

$\mathrm{N}=205 . \alpha=.05 / 8=.00625$ (Bonferroni correction).

Table 2. Responses to the open-ended question - the respondents' comments on their motivation to engage in English-to-Papiamentu lexical transfer

\begin{tabular}{|l|c|r|r|r|r|r|}
\hline $\begin{array}{l}\text { Respondents reasons } \\
\text { for English-to- } \\
\text { Papiamentu lexical } \\
\text { transfer }\end{array}$ & $\begin{array}{c}\text { Exclusive } \\
\text { translators } \\
\mathrm{n}=51\end{array}$ & $\begin{array}{c}\text { Translators- } \\
\mathrm{and}-\text {-writers } \\
\mathrm{n}=49\end{array}$ & $\begin{array}{c}\text { Non- } \\
\text { translators } \\
\mathrm{n}=105\end{array}$ & $\begin{array}{c}\text { All } \\
\text { translators } \\
\mathrm{n}=100\end{array}$ & $\begin{array}{c}\text { All non- } \\
\text { translators } \\
\mathrm{n}=105\end{array}$ & $\begin{array}{c}\text { All } \\
\text { respond- } \\
\text { ents } \\
\mathrm{N}=205\end{array}$ \\
\hline $\begin{array}{l}\text { Variety of expressions } \\
\text { flexibility for clarity }\end{array}$ & $28(.55)$ & $19(.39)$ & $24(.23)$ & $47(.47)$ & $24(.23)$ & $71(.35)$ \\
\hline $\begin{array}{l}\text { Wider readership / } \\
\text { popularity on the } \\
\text { Internet }\end{array}$ & $6(.12)$ & $14(.29)$ & $27(.26)$ & $20(.20)$ & $27(.26)$ & $47(.23)$ \\
\hline $\begin{array}{l}\text { Globalisation / } \\
\text { Internet technology }\end{array}$ & $6(.12)$ & $14(.29)$ & $27(.26)$ & $20(.20)$ & $27(.26)$ & $47(.23)$ \\
\hline $\begin{array}{l}\text { Client satisfaction / } \\
\text { employment stability }\end{array}$ & $13(.25)$ & $4(.08)$ & $3(.03)$ & $17(.17)$ & $3(.03)$ & $20(.10)$ \\
\hline $\begin{array}{l}\text { Lack or disuse of } \\
\text { specialised terms }\end{array}$ & $6(.12)$ & $4(.08)$ & $16(.15)$ & $10(.10)$ & $16(.15)$ & $26(.13)$ \\
\hline $\begin{array}{l}\text { The status of } \\
\text { Papiamentu as an } \\
\text { official language }\end{array}$ & $1(.02)$ & $3(.06)$ & $6(.06)$ & $4(.04)$ & $6(.06)$ & $10(.05)$ \\
\hline $\begin{array}{l}\text { Consumer appeal / } \\
\text { marketing }\end{array}$ & $3(.06)$ & $0(.00)$ & $9(.09)$ & $3(.03)$ & $9(.09)$ & $12(.06)$ \\
\hline Nothing & $3(.06)$ & $7(.14)$ & $15(.14)$ & $10(.10)$ & $15(.14)$ & $25(.12)$ \\
\hline
\end{tabular}

